\title{
Revitalizing Local Wisdoms for Dealing with the Disruption Era: A Case of Aceh
}

\author{
J Usman ${ }^{1}$; Syabuddin²; Gunawan ${ }^{3}$; Sulaiman $^{4}$, Fauzan $^{5}$ \\ Faculty of Education and Teacher Training, \\ Ar-Raniry State Islamic University, Banda Aceh ${ }^{1,2,3}$ \\ Perguruan Tinggi Ilmu Al Quran (PTIQ) Aceh ${ }^{4}$ \\ Graduate of Faculty of Dakwah and Communication, \\ Ar-Raniry State Islamic University, Banda Aceh ${ }^{5}$ \\ \{jarjani@ar-raniry.ac.id $\left.{ }^{1,2,3,4,5}\right\}$
}

\begin{abstract}
Living in the globalized era is very challenging because it has tremendously disrupted the shared local wisdom as the people's principles of life in many countries. In an Indonesian province of Aceh, for instance, as the result of the erosion of local wisdom today, many people have dared to sporadically violate social norms and values. This descriptive-qualitative research employed document analysis and interviews to analyze the local wisdom from various sources, such as textbooks, proverbs, idioms, etc. and clarified their values with old people in Aceh. It was found that there are many local pearls of wisdom in Aceh culture, as in social structure (e.g., geuchiek, tuha peut), social practices (e.g., ba breuh lam jeumpét, meuseuraya), and proverbs that can be synergized for dealing with disruption era. Each of those wisdom has vital values of virtue, such as education, commitment, work ethics, gratitude, etc. Therefore, these Islamic religious-based local wisdom should be revitalized by incorporating them into school lesson materials in which students learn to know and act based on their vital cultural values.
\end{abstract}

Keywords: Local Wisdom, Aceh Culture, Globalization

\section{Introduction}

Every society has its unique local wisdom to deal with their daily life problems. Local wisdom refers to the respected and adhered policy of life, views, wise ways of life, passed through generations through oral traditions (e.g., proverbs, fairy tales), written traditions (manuscripts), and the used objects[1] [2]. It also encompasses philosophy, values, norms, ethics, rituals, beliefs, habits, customary laws, and so forth [3]. Similarly, Aceh society that has been established for hundred years before the independence of Republic of Indonesia, especially during the reigns of a series of kingdoms, has lots of cultures in all sectors of life, ranging from culture, politic, government, occupations, social and society, worship, economy, education, to conservation of nature [4].

Several studies have been carried out attempting to uncover the local wisdom in Aceh. Among them was by Nurdin [5] on revitalizing Aceh local wisdom on settling conflicts in society, such as through peusjieuk and peumat jaroe and by Nucifera and Hidayat [6] on local 
wisdom in media literacy. These local wisdom have potencies in solving social problems within Aceh society [7]. Those social practices have served as the glue for holding people together in Aceh for a long time. That is why Aceh society was strong in dealing with various problems, including defending Aceh from the invasion of colonials.

Moreover, local wisdom in Aceh society is based on Islamic values [1]. The nexus between Aceh and Islam can also be understood from an old maxim in Aceh "Hukôm ngön adat lagèe zat dengan sifeut" [4], which means Islamic law and customs are like the thing and its nature [1] [8]. That is a reason that in any social event and arts in Aceh, people are invited to remember Allah.

Unfortunately, many local pearls of wisdom in Aceh have faded and been ignored today because of the negative effects of globalization. Kolb [9] defines globalization as "the growing interdependence of the world's economies, cultures, and populations, brought about by crossborder trade in goods and services, technology, and flows of investment, people, and information" (p.1). Globalization offers not only advantages but also disadvantages such as tremendously disrupting the shared local wisdom. Jati [10] states that the perished of local wisdom can negatively affect conflicts as people no longer have cultural filters. Accordingly, local people are now mostly governed by borrowed principles of life, including in the education sector [11] [12]. The force of neoliberalism has immensely affected national policies in many countries [13] [14] [15], including Indonesia.

Another factor that has paralyzed local wisdom in Aceh is the policy of Indonesia's authoritarian Orde Baru Regime for over thirty years and colonialism. For the reason of uniformity policy through regulation No. 5 in 1979, many adat or customary laws have been removed [16]. Many local names have been replaced with "imported names", such as, "gampông" to "desa", and people gathering together as an adat were suspected during the armed political conflicts for 30 years [17] [18] [19] [20] [21]. Accordingly, many of the adat traditions as well as their values have been submerged [1] and removed since then from local people's minds. During the Dutch colonial, much local wisdom, such as dayah, was destroyed [22].

Therefore, it is important to research revitalizing the local wisdom in Aceh in dealing disruption era. This study explores the values of the virtue of the local wisdom and attempts to uncover these values for people's lives in the disrupting era.

\section{Method}

This descriptive-qualitative research employed document analysis and interviews to collect data on local wisdom from various sources, such as textbooks, proverbs, idioms, etc. and clarified their values with old, knowledgeable Acehnese people in Aceh. Ten people who are considered as having a common understanding of Aceh local wisdom were interviewed, including the head of Majelis Adat Aceh (MAA), lecturers of Aceh history course, Acehnese linguists, village leaders, and old people. They were selected based on snowball sampling by selecting respondents based on the information from the first interviewed respondents [23]. Data were validated by involving various resources to deal with the same thing.

The data were analyzed by using Miles, Huberman, and Saldana's procedures [24], ranging from reading data closely, data reduction, coding, to drawing conclusions. Two stages were involved in the process of data analysis, including a vertical analysis and horizontal analysis. In vertical analysis, the results of the respondents' interviews were analyzed separately, 
whereas in horizontal analysis they are analyzed by comparing the common patterns and differences of the data.

\section{Result and Discussion}

\section{Traditional Institutions}

\section{Geuchiek}

Geuchiek is a village leader who plays important roles in solving various social problems at the village level in Aceh society. Etymologically, geuchiek is a noun derived from the adjective chiek, meaning old or mature and the prefix geu-. Thus, geuchiek is a person who has been matured in various fields (including religious and socio-cultural fields) so that he or she is qualified to be selected to lead the village or villagers. So, a geuchiek is not just a person who has obtained the highest votes in geuchiek public election but also has been mature socially and religiously. A geuchiek needs to know adat, as it is a significant part of the life as in a proverb "Maté aneuk mupat jrat, maté adat pat tamita" can be literally translated "the death of a child, we know the tomb; the death of adat, nowhere to find it." This means that it is very important to maintain adat in Aceh society.

However, today anyone can be elected as a geuchiek, even the perpetrators of crimes. Hence, it is not uncommon for community distrust to occur. Moreover, the word geuchiek was replaced to kepala desa by by the New Order government. Although at first glance it looks the same, for the people of Aceh, the meaning of kepala desa (village head) is not as strong as that of geuchiek. The kepala desa is only the head of the person who heads a village, regardless he is a chiek or not in the village.

\section{Gampông}

Gampông is derived from the word pông, which is a home-base in a baseball game, a place to reach back to get points. If a hitter has reached pong on his running from base 1, then he is safe. Therefore, the position must be remembered and guarded. Similarly, gampong contains a social identity for Acehnese people. However, during the New Order government, gampong was once erased and replaced with desa, an "imported" word that does not take root from local culture nor give significance for the people in Aceh.

\section{Teungku Imum}

Teungku Imum is an important apparatus in the village social structure in Aceh. Teungku Imum is responsible for dealing with religious matters in the village, ranging from leading prayers to doing rituals for burying the dead person. Therefore, those who are appointed as imum are people who are already well-established in the field of Islamic religion and have good competence in athletes, such as communication skills with the wider community. These competencies are important given the strategic role of teungku imum for the religious life of the people in Aceh. In the past, because of his high authority, teungku imum was highly valued and his commands were heard.

\section{Tuha Peut}

Tuha Peut are people who are elected as legislators in a village. These people are considered to be the mouthpiece of the community as well as the executive work controller (geuchiek and teungku imum). Therefore, Tuha Peut has great power and authority to help determine the good and bad life of the village community. Tuha peut come from the words tuha (old) and peut (four) 
are four people who are elder or considered to have a role as parents who have the experience, insight as well as the ability to help the community. Therefore, when developing villages, as programmed by the Central Government, the role of the peut must be revitalized.

\section{Dayah/balee beut}

Dayah/balee beut is a traditional Islamic school in Aceh, which is also called pesantren. Dayah and balee beut are both Islamic schools, but the former is bigger in size and time of operation. Dayah is not established at every village, where balee beut is. Commonly balee beut is operated at night during which children in the village learn the Quran and kitab (books on how to practice Islam). Dayah is commonly established in every sub-district where people of various ages study there for free. More importantly, dayah/balee beut has established long before secular education exists in Aceh [22].

Through the establishment of dayah/balee beut, people in Aceh want to show their commitment to educating their generations with religious matters. Every child is required to learn Islam. That was why most people in Aceh were able to read the Quran and practice Islam well. Even, children in villages were not only controlled by their parents, but also by their whole villagers. Everyone in the village was responsible for preventing and protecting a child from doing the bad behavior. It was like a proverb "it takes one village to raise a child."

\section{Panglima Laot, Keujruen Blang, Panglima Uteuen}

Panglima Laot, Keujruen Blang, and Panglima Uteuen are traditional institutions in Aceh that are responsible for various jobs. Panglima Laot is a sea commander, which is part of the traditional institution in Aceh responsible to deal with various routines and problems on the sea. It is panglima laot who thinks about the welfare of sailors and people around the beach. Keujruen Blang is an important position in the social structure of Aceh society. They are recruited to manage planting issues and irrigation in the rice fields or farms. Sharing the flow of irrigation water is among the tasks of the assigned person for keujruen blang. Panglima Uteuen is the forest commander or ranger in Aceh society. They are responsible for Among their responsibility is to keep the forest from being used excessively. In this way, people in Aceh show high concern about their environmental sustainability. This is an indication that people in Aceh have a good commitment to environmental preservation as forests provide valuable resources for human beings.

\section{Cultural Practices}

\section{Ba Ranub}

$B a$ Ranub literally means bringing betel. It is the tradition of the engagement process of a girl for a wife in Aceh society. During the process, two stacks of betel, stack one of seven leaves and stack two of five leaves are usually brought by the head of the village and his companions to act on behalf the family of the would-be bridge comes to a girl's house to engage her. For local people in Aceh, seven leaves and five leaves of betel have important meanings. Seven means seven days a week and five means five times a day the future family need to do prayer, including shubuh, zuhur, ashar, maghrib, and isya. Moreover, the old people in Aceh want to remind their generations that marriage is a serious and sacred act. They are responsible for Allah. 


\section{Ba Breueh Lam Jeumpét}

The Acehnese tradition is generally carried out by mothers in a village. The meaning is very important. For example, the help and emancipation in Aceh society are so great, which is not only done by men, but also by women. In the tradition of this new breed of jeumpet, women bring one liter of rice which is put into sacks made from mendong weeds (eumpang jeumpét) to the houses of people who are doing festivity. It is surely intended for the host to reduce the burden of holding a festivity event with the help of mothers.

\section{Duek Pakat}

Duek pakat is a tradition of the people of Aceh, which means meeting together to reach a decision on a certain matter in society. The tradition of duat pakat is often used by the people of Aceh in dealing with big events, such as weddings, village events, and others. In this duek pakat has contained a lot of values, namely togetherness in dealing with something, helping, and tightening the ties of friendship. In the twelfth agreement before the wedding party of citizens, for example, all members of the community are invited to give advice and jointly determine who does what.

\section{Meuleumak}

Meuleumak is a traditional way of cooking yellow rice and eating together among the male youths at the village level in Aceh. Through tradition, youths collect money together from each other to buy rice, fish, meat, and other ingredients. They then cook and eat together in meunasah at night. A similar thing is practiced by both male and female students at balee seumeubeut (small Islamic night boarding school) in villages in Aceh. This tradition offers many values for the people in Aceh. Among them are practicing cooking among youths, togetherness, working together, and sharing things together in fairness. However, this tradition has been less practiced today.

\section{Meuripèe}

Meuripèe is the tradition of helping people through fundraising among the villagers in Aceh. This mechanism has also been used in supporting a family who is doing ceremonies, such as costly wedding ceremonies, supporting who are suffering from calamity, supporting youth activities, and supporting mums' activities in the village. In meuripèe, villagers donate some money or rice to be handed into the activities or family.

\section{Meuseuraya}

Meusuraya is mutual cooperation or working bee in which people in the village are doing a job for charity. Among the jobs are cleaning sewer together. Villagers of any social status collaboratively work to prepare a village event, such as celebrating maulid of the Prophet Muhammad, important guest visit, wedding ceremony, etc. In toroyong is embedded various values ranging from working together, environmental conservation awareness to commitment.

\section{Proverbs}

\section{"Nyo kapakat, lampoh jrat tapeugala"}

This is a proverb in Acehnese society, which has important values in life. The meaning is that if an agreement has been reached together, the cemetery land can be mortgaged. The fact is that mortgaging the grave ground is taboo in Acehnese society. This shows that meeting for reaching 
an agreement is prioritized in Acehnese society. A decision in deliberation has a vital role as if it can make possible the impossible one.

\section{“Tajak beulaku linggang, tapinggang beulaku ija”}

This message implies that we should live according to our own abilities and using what we have, and do not be jealous of other people's possessions. If we live by the standards of what other people are capable of and what people have, we will not be happy. Moreover, a person's standard of living certainly varies. We will always be restless and insecure in life if we do not like what we can work for ourselves.

This message is indeed very laden in its meaning for one's life. Moreover, disputes or quarrels in society, are often triggered by the existence of elements who like to take the rights of others, including rights in politics, using the highway, sharing property, the right to speak, and others.

\section{"Tameugurèe bèk tatirèe-tirèe"}

The saying literally means "Learn from the teacher, do not imitate." This suggests that it is crucial to learn something from a knowledgeable person or authority in order to avoid making wrong interpretations, particularly about religious matters. In the globalized era, it is very likely for everyone to take on information from various online resources for ways of life that may be misleading. Therefore, checking with teachers is indispensable.

"Poma ngön ayah seureuta gurèe, ureung nyan banlhèe beuna taturot. Meunyo na salah meuah talake, tasujud ulee tacôm bak teuôt”

It literally means that the father, mother, father, and teacher are the three persons that must be obeyed. If we make a fault with them, we must apologize by bending down to kiss their knee. This saying characterizes the teaching and learning process. Teachers are central in nearly all activities, including learning as well as other social activities. Moreover, using corporal punishment when students were disobedient to teachers during school hours or did not reach the expected learning outcomes were commonly accepted or not considered as a power abuse in Aceh. That is why students strived to learn as hard as possible to meet the teachers' expectations. Consequently, most of the students were good at memorizing math formulae, calculating, memorizing the Qur'an verses, and so forth. These outcomes make some local people claim that education in the past was better than today.

"Meunyo kön ie, leuhop; meunyo kon droe, gob."

This can be literally translated "If not water, mud; if not us, others". Through this saying, we are reminded to wisely live on the earth. We must be selective, not to quickly take on every value that comes to us in our life. It is important to use our own norms and cultures in our life, no matter where we live.

\section{“Buya krueng teudöng-döng, buya tamöng meuraseuki”}

This proverb can be literally translated: Local river crocodiles are just standing, the coming crocodiles are grabbing the profits. It means that local people are watching the profits earned by the newcomers. Through this proverb, people remind their young generations to study hard in order not to be watchers when many other people come in to get profits. 


\section{"Bèk tapula lada watèe trôk kapai”"}

This proverb literally means "Don't plant the pepper when the ship is coming." Through this saying, we are reminded not to miss many golden chances in our life. We need to anticipate any change in our lives and prepare for our future. In this proverb, it can be understood several important values, such as hard work, long-life learning, and future-oriented mind. In this globalized era, these are among the values crucial to have since everything rapidly changes and uncertainties are high.

\section{"Meubalék cak, meutuka cok"}

The saying can be literally translated into "The clumps of soil upside down, the wrong one is taken" which means that we are no longer able to take the priority in our life. If not selected the life principles with care, it is very likely to take the wrong thing and leave the right one in or daily life. In regard to culture, this proverb intends to remind people not to appropriate other cultural values while ignoring the values of our own cultures.

\section{Conclusion}

From the findings on the existence of the traditional institutions, it can be understood that the development at the village level was emphasized in Aceh in the past. It is a reason that gampong (village) was powerful enough in dealing with routine activities and solving all social problems in Aceh. All the local wisdom provides values for dealing with disruption era; therefore, it is crucial for the government and non-governmental organizations to revitalize them through various, such as incorporating in the local content curriculum. Moreover, the benefits of revitalizing local wisdom as revealed from existing studies [25] [26] [27] [28] should be convincing underpinnings that encourage the government and non-governmental organizations to work together with local people in revitalizing and maintaining the local wisdom.

\section{References:}

[1] N. Abdurrahman, "Beberapa catatan tentang kearifan lokal masyarakat Aceh.," 2015. [Online]. Available: https://maa.acehprov.go.id/news/detail/beberapa-catatan-tentangkearifan-lokal-masyarakat-Aceh.. [Diakses 20 August 2019].

[2] Koentjaraningrat, Manusia dan kebudayaan di Indonesia, Jakarta: Penerbit Djambatan, 1993.

[3] M. Rohmadi dan L. Hartono, Kajian bahasa, sastra dan budaya jawa: teori dan pembelajarannya, Jakarta: Pelangi Press, 2011.

[4] A. Nurdin dan F. Kasim, "Resolusi Konflik Berbasis Adat di Aceh: Studi tentang azas dan dampaknya dalam membangun perdamaian di Lhokseumawe," dalam ARICIS Proceedings, Banda Aceh, 2017.

[5] A. Nurdin, "Revitalisasi kearifan lokal di Aceh: Peran budaya dalam menyelesaikan konflik masyarakat," Analisis, vol. 8, no. 1, pp. 135-154, 2013.

[6] P. Nucifera dan M. Hidayat, "Literature as a source of local wisdom," dalam Proceedings of the 28th International Conference on Literature, Banda Aceh, 2019. 
[7] Y. Yusuf, Peutua beuna: Kearifan lokal masyarakat Aceh, Banda Aceh: Majelis Adat Aceh, 2008.

[8] M. Husein, Adat Atjeh, Banda Aceh: Dinas Kebudayaan Provinsi Daerah Istimewa Aceh, 1970.

[9] M. Kolb, "What is globalization?," 2018. [Online]. Available: https://www.piie.com/microsites/globalization/what-is-globalization.html. [Diakses 19 August 2019].

[10] W. Jati, “Kearifan lokal sebagai resolusi konflik keagamaan,” Walisongo, vol. 21, no. 2, pp. 393-416, 2013.

[11] Y. Sung, "Cultivating borrowed futures: The politics of neoliberal loanwords in South Korean cross-national policy borrowing," Comparative Education, vol. 47, no. 4, pp. 523$538,2011$.

[12] L. Lim, "Globalization, the strong state and education policy: the politics of policy in Asia," Journal of Education Policy, 2016.

[13] S. Ball, "The reluctant state and the beginning of the end of state education," Journal of Educational Administration and History, vol. 44, no. 2, pp. 89-103, 2012.

[14] S. Ball, "What is policy? 21 years later: Reflections on the possibilities of policy research," Discourse: Studies in the Cultural Politics of Education, vol. 36, no. 3, pp. 306$313,2015$.

[15] H. Rizvi dan B. Lingard, Globalizing education policy, London: Routledge, 2010.

[16] Tim Peneliti, P. K. P. M., Penerapan Alternatif Dispute Resolution Berbasis Hukum Adat pada Lembaga Keujreun Blang di Kabupaten Aceh Besar, Banda Aceh: BRR Sarpras Hukum dengan PKPM, 2007.

[17] S. M. Ahmad dan Y. Dinamika, Aceh bersimbah darah: mengungkap penerapan status daerah operasi militer (DOM) di Aceh, 1989-1998, Jakarta: Pustaka Al-Kautsar, 1999.

[18] E. Aspinal, The Helsinki agreement: A more promising basis for peace in Aceh?, Washington, D.C.: East-West Center Washington, 2005.

[19] S. A. K. Rafiie, A. Husni dan S. Atah, "Acehnese wars and learning from 12 years of peace in Aceh," Analisa: Journal of Social Science and Religion, vol. 2, no. 2, pp. 161$181,2017$.

[20] M. Davies, Indonesia's war over Aceh: Last stand on Mecca's porch, Routledge, 2006.

[21] A. Reid, "War, peace and the burden of history in Aceh," Asian Ethnicity, vol. 5, no. 3, pp. 301-314, 2004.

[22] E. Srimulyani, “ Islamic Schooling in Aceh: Change, Reform, and Local Context," Studia Islamika, vol. 20, no. 3, pp. 467-487, 2013.

[23] N. Denzin dan Y. Lincoln, The landscape of qualitative research, 4th penyunt., Thousand Oaks, CA: Sage, 2013.

[24] M. B. Miles, A. M. Huberman dan J. Saldana, Qualitative data analysis: A methods sourcebook, 3rd penyunt., Los Angeles, CA: Sage Publications, 2014.

[25] S. Jayadi, A. Demartoto dan D. T. Kartono, "Local Wisdom as the Representation of Social Integration between Religions in Lombok Indonesia," dalam Annual Civic Education Conference (ACEC), 2018. 
[26] D. Miller, Positive child guidance, 6th penyunt., Belmont, CA: Woodsworth Cengage Learning, 2013.

[27] A. Ratana-Ubol dan J. Henschke, "Cultural learning processes through local wisdom: a case study on adult and lifelong learning in Thailand," International Journal of Adult Vocational Education and Technology, vol. 6, no. 2, pp. 41-60, 2015.

[28] H. K. Surtikanti, A. Syulasmi dan N. Ramadhani, "Traditional knowledge of local wisdom of Ammatoa kajang tribe (South Sulawesi) about environmental conservation," Journal of Physics, vol. 895, pp. 1-10, 2017. 